\title{
Kontribusi Genomika dalam Penemuan Gen Toleran Salinitas Tanaman Padi
}

\section{Contribution of Genomics to Gene Discovery of Salinity Tolerance in Rice}

\author{
Bagus Herwibawa*), Florentina Kusmiyati \\ Laboratorium Fisiologi dan Pemuliaan Tanaman, Fakultas Peternakan dan Pertanian, \\ Universitas Diponegoro \\ Kampus Tembalang, Semarang 50275, Jawa Tengah, Indonesia \\ *Penulis untuk korespondensi E-mail: bagus.herwibawa@live.undip.ac.id
}

\begin{abstract}
Adverse environmental conditions, such as salinity, are major challenges limiting the productivity of rice. Salinity tolerance is highly complex and involves many genes. Therefore, it is difficult to conclude universally how rice responds to salinity. We aimed to explain the contribution of genomics to gene discovery of salinity tolerance in rice. Currently, genomics has contributed to the discovery of salinity tolerance related genes in rice, by comparative genomic and genome-wide association studies. The development of a genome database is also useful for identifying gene families related to salinity tolerance between species, based on homology and synteny. The obtained genes related to salinity tolerance can be used in marker-assisted backcrossing, marker-assisted selection, and genomic selection, however, the genes are not optimally used. The use of new tools, such as genetic engineering and genome editing are provided newer and faster avenues to generate salt-tolerant rice. However, both tools also are not much used the obtained salinity tolerant genes. The research trends in online databases are predicted to continue to increase because it is cheap, relatively easy, and capable to produce predictive data. The databases, of course, must be able to be used by all researchers and plant breeders in Indonesia.
\end{abstract}

Keywords: Abiotic stress, gene identification, genome-wide association study, rice improvement, whole genome sequencing.

\section{INTISARI}

Kendala abiotik seperti salinitas, merupakan tantangan utama yang menjadi pembatas produktivitas tanaman padi. Sifat toleran salinitas sangat kompleks dan melibatkan banyak gen. Oleh sebab itu sangat sulit menyimpulkan bagaimana tanaman padi merespon cekaman salinitas. Artikel ini bertujuan untuk menjelaskan kontribusi genomika dalam penemuan gen toleran salinitas tanaman padi. Saat ini, genomika telah berkontribusi dalam penemuan gen toleran salinitas tanaman padi, khususnya melalui genomika komparatif dan kajian asosiasi lintas genom. Pengembangan pangkalan data genom juga bermanfaat untuk mengidentifikasi famili gen yang berkaitan dengan toleransi salinitas antar spesies berdasarkan homologi dan sintaksis. Gen-gen toleran salinitas yang ditemukan dapat dimanfaatkan melalui silang balik berbantuan penanda, seleksi berbantuan penanda, dan seleksi genomik, namun hingga saat ini gen-gen tersebut belum secara optimal dimanfaatkan. Penggunaan teknik baru, seperti rekayasa genetika dan pengeditan genom juga menjadi metode baru dan cepat 
untuk menghasilkan tanaman padi toleran salinitas. Meskipun demikian, kedua pendekatan tersebut juga belum banyak memanfaatkan gen-gen toleran salinitas yang telah ditemukan. Tren penelitian pangkalan data berbasis web diperkirakan akan terus meningkat karena murah, relatif mudah, dan mampu menghasilkan data prediktif. Pangkalan data yang akan terus berkembang, tentu harus dapat dimanfaatkan oleh peneliti dan pemulia tanaman di Indonesia.

Kata kunci: Cekaman abiotik, identifikasi gen, kajian asosiasi lintas genom, pengurutan genom lengkap, perbaikan tanaman padi.

\section{PENDAHULUAN}

Salinitas merupakan kendala abiotik paling serius yang membatasi produktivitas hampir semua tanaman (Gupta dan Huang, 2014). Lahan salin (> $6 \mathrm{dS} / \mathrm{m}$ ) bahkan menyebabkan hasil tanaman padi menurun 50 - 100 \% (Rad dkk., 2012). Salinitas bertanggung jawab terhadap dua bentuk cekaman, yaitu cekaman osmotik dan ionik (Kusmiyati dkk., 2019). Cekaman osmotik disebabkan oleh defisit air pada jaringan tanaman selama fase awal cekaman salinitas, sementara cekaman ionik disebabkan adanya akumulasi $\mathrm{Na}^{+}$dan $\mathrm{Cl}^{-}$serta ganggungan rasio $\mathrm{Na}^{+} / \mathrm{K}^{+}$pada sel tanaman (Horie dkk., 2012). Akibatnya, ada peningkatan produksi spesies oksigen reaktif pada tanaman padi yang memiliki sifat sensitif salinitas (Chutimanukul dkk., 2018). Meskipun demikian, terdapat sistem antioksidan yang berfungsi untuk mendetoksifikasi spesies oksigen reaktif yang dapat menjadi fokus pemuliaan tanaman padi (Kaewneramit dkk., 2019). Upaya perakitan tanaman padi toleran salinitas masih terhambat karena mekanisme toleran salinitas dan gen-gen yang mengontrolnya belum sepenuhnya dipahami (Lekklar dkk., 2019a).

Filipina telah berhasil merakit tanaman padi varietas PSBRc 50 "Bicol" yang bersifat toleran salinitas setelah 10 tahun penelitian (1985 - 1995) (Senadhira dkk., 2002). Satu dekade kemudian India dilaporkan memiliki beberapa varietas padi toleran salinitas, antara lain varietas SR 26 B, CSR 1, CSR 2, CSR 3, CSR 27, CSR 13, Panvel 1, Panvel 2, Panvel 3, Vytilla 1 dan Vytilla 2 yang khusus dikembangkan untuk daerah pantai, dan varietas CSR 10 dengan keunggulan tinggi tanaman sedang, hasil tinggi dan umur genjah (Sankar dkk., 2011). Balai Besar Penelitian Tanaman Padi Indonesia juga telah menghasilkan varietas padi toleran salinitas meskipun jumlahnya masih sedikit, antara lain varietas Dendang, Lambur, dan Purwa yang dideskripsikan bersifat agak toleran salinitas, serta Inpari 34 Salin Agritan, Inpari 35 Salin Agritan, dan Inpari Unsoed 79 Agritan yang dideskripsikan bersifat toleran salinitas pada fase bibit (BB Padi, 2010; BB Padi, 2018). Penelitian untuk menghasilkan varietas toleran salin terus dilakukan, dan salah satu metode yang populer adalah pemetaan lokus sifat kuantitatif. Lokus sifat 
kuantitatif untuk sifat toleran salinitas telah dideteksi pada tanaman padi, namun beberapa di antaranya merespon cekaman kekeringan dan salinitas (Hao dkk., 2010).

Pemetaan lokus sifat kuantitatif hanya dapat mengidentifikasi keragaman alelik yang bersegregasi antara tetua persilangan F2 atau dalam galur inbrida rekombinasi, serta resolusi pemetaan yang terbatas oleh banyaknya rekombinasi genetik yang terjadi pada populasi pemetaan. Penentuan genotip dengan penanda mikrosatelit berdasarkan reaksi berantai polimerase juga membatasi untuk melihat variasi, dan melelahkan, serta membutuhkan banyak waktu, dan ketika menentukan genotip dengan densitas tinggi membutuhkan banyak peneliti (Huang dan Han, 2014). Saat ini, lokus sifat kuantitatif untuk sifat toleran salinitas pada tanaman padi dapat dipetakan pada tingkat nukleotida, menggunakan pendekatan kajian asosiasi lintas genom dan transkriptom, karena selama beberapa tahun terakhir pengurutan sekuens generasi kedua telah digunakan untuk menghasilkan data genomik yang akurat dalam jumlah besar secara cepat. Metode tersebut telah menjadi pendekatan yang kuat untuk kajian genomika fungsional dan pemuliaan tanaman molekuler. Artikel ini bertujuan untuk menjelaskan kontribusi genomika dalam penemuan gen toleran salinitas tanaman padi.

\section{PANGKALAN DATA GENOM BERBASIS WEB}

Pengembangan dan penerapan teknologi pengurutan sekuens generasi kedua memungkinkan untuk membaca ratusan pasang basa DNA, secara cepat dengan harga yang lebih murah dibandingkan metode Sanger (Pereira dkk., 2020). Platform yang digunakan antara lain SOLiD/lon Torrent PGM (Life Sciences), Genome Analyzer/HiSeq 2000/MiSeq (Illumina) dan GS FLX Titanium/GS Junior (Roche), yang mana masingmasing platform tersebut memiliki mekanisme yang berbeda dengan keunggulan yang saling melengkapi (Liu dkk., 2012). Saat ini, teknologi pengurutan sekuens yang lebih baru telah dikembangkan dengan keunggulan mampu membaca urutan molekul DNA/RNA yang berasal dari molekul tunggal $(<1 \mu \mathrm{g})$, sehingga tidak diperlukan amplifikasi reaksi berantai polimerase dan terhindar dari bias yang disebabkan oleh amplifikasi tersebut. Teknologi ini dikenal dengan pengurutan sekuens generasi ketiga dan generasi keempat. Platform yang digunakan untuk generasi ketiga yang tersedia saat ini adalah Helioscope dan PacBio, sementara untuk generasi keempat adalah GridION dan MinION (Cubero dkk., 2017).

Data sekuens yang dihasilkan generasi ketiga dan keempat lebih rendah dengan tingkat kesalahan yang masih tinggi dibandingkan dengan generasi kedua. Oleh sebab itu, generasi ketiga dan keempat masih belum mampu menggantikan kemampuan 
generasi kedua dalam pengurutan sekuens, terutama organisme tingkat tinggi. Namun semuanya mampu mempercepat pemetaan sekuens genom acuan berbagai spesies tanaman, dari tanaman model hingga tanaman budi daya yang memiliki nilai ekonomi tinggi. Kondisi tersebut juga telah menciptakan berbagai peluang penemuan gen-gen dan jalur-jalur transduksi sinyal yang berkaitan dengan toleransi salinitas. Sebagai contoh, sekuens hasil pengurutan genom generasi kedua telah digunakan untuk mengidentifikasi gen-gen kandidat toleran salinitas berdasarkan pemetaan genom acuan pada tanaman padi secara in silico (Abhayawickrama dkk., 2020). Peta genom acuan merupakan fondasi untuk penemuan gen-gen penting yang berkontribusi pada karakter bernilai ekonomi, dimana bioinformatika hingga saat ini telah terbukti sebagai alat yang kuat untuk mengidentifikasi variasi genetik lintas genom.

Analisis genom dilakukan dalam rangka penemuan varian baru, gen, ataupun lokus sifat kuantitatif, untuk karakter-karakter bernilai ekonomi tinggi yang diharapkan dapat mengakselerasi program pemuliaan tanaman padi, khususnya sifat toleran salinitas. Penggabungan sifat yang lebih baik sehingga terekspresi bersama-sama, membutuhkan sumber daya genetik yang menyediakan materi dasar untuk perakitan varietas unggul baru. Saat ini, lebih dari 7 juta aksesi berbagai spesies tanaman dikonservasi di 1.750 bank plasma nutfah seluruh dunia, dimana sekitar 2 juta aksesi diperkirakan unik (Fu, 2017). Meskipun demikian, hanya sebagian kecil dari koleksi tersebut yang telah dimanfaatkan karena kurangnya informasi mengenai karakter yang bernilai ekonomi. Upaya tersebut dapat dilakukan dengan memperbaiki metode karakterisasi genotip (genotyping) dan karakterisasi fenotip (phenotyping), serta meningkatkan akses untuk mendapatkan materi genetik dari berbagai negara. Investasi yang sangat besar dibutuhkan untuk menyediakan sekuens dalam studi genomika pada awalnya, terutama berkaitan dengan sumber daya manusia dan pendanaan.

Draf sekuens genom tanaman padi pertama kali dilaporkan pada tahun 2002, untuk kedua sub spesies: Indica (Yu dkk., 2002) dan Japonica (Goff dkk., 2002), dengan hasil sementara mencapai 466 mega basa (Mb) (Indica) dan 420 Mb (Japonica) (92 $93 \%$ ukuran genom tanaman padi). Sekuens tersebut diperkirakan memiliki 30 - 50 ribu gen, dengan rerata kandungan basa GC sebesar 44\%. Laporan tersebut juga menyatakan bahwa terdapat $49,5 \%$ prediksi gen tanaman padi yang homolog dengan gen Arabidopsis thailana. Saat ini, data genom lengkap 3.024 kultivar tanaman padi telah tersedia melalui The 3,000 Rice Genome Project (3K RGP), di antaranya adalah kultivar Seeragasamba (Indica) yang menghasilkan 42,6 × 106 data mentah (Bindusree dkk., 2017). Meskipun demikian, pengurutan sekuens terus berlangsung, baru-baru ini genom 
lengkap kultivar KitaakeX (Japonica) juga tersedia, dengan ukuran genom sebesar 409,5 Mb dan mengandung 33.226 gen fungsional (Jain dkk., 2019). Peta sekuens genom tanaman padi telah menjadi fondasi dan acuan bagi peneliti untuk menganalisis variasi genom berbagai aksesi plasma nutfah, termasuk kerabat liar tanaman padi. Saat ini, pangkalan data genom berbasis web terus dikembangkan dan telah menjadi sumberdaya substansial untuk membantu program pemuliaan tanaman (Tabel 1).

Tabel 1. Pangkalan data sekuens genom

\begin{tabular}{|c|c|c|}
\hline Nama & Alamat web & Spesies Tanaman \\
\hline $\mathrm{NCBI}$ & https://www.ncbi.nlm.nih.gov/genome/ & multi spesies \\
\hline EnsembIPlants & https://plants.ensembl.org/index.html & multi spesies \\
\hline Gramene & http://www.gramene.org/ & multi spesies \\
\hline GrainGenes & https://wheat.pw.usda.gov/GG3/ & multi spesies \\
\hline VISTA & http://genome.lbl.gov/vista/index.shtml & multi spesies \\
\hline KEGG Plant & https://www.genome.jp/kegg/genome/plant.html & multi spesies \\
\hline PlantGDB & http://www.plantgdb.org/ & multi spesies \\
\hline Phytozome & https://phytozome.jgi.doe.gov/pz/portal.html & multi spesies \\
\hline PGDB & http://pgdbj.jp/plantdb/plantdb.html?|n=en & multi spesies \\
\hline KewSciences & https://cvalues.science.kew.org/?querytype=1 & multi spesies \\
\hline PGDD & http://chibba.agtec.uga.edu/duplication/ & multi spesies \\
\hline TAIR & https://www.arabidopsis.org/ & multi spesies \\
\hline PLAZA & https://bioinformatics.psb.ugent.be/plaza/ & multi spesies \\
\hline RAP-DB & https://rapdb.dna.affrc.go.jp/ & Oryza sativa \\
\hline IRGSP & https://rgp.dna.affrc.go.jp/E/IRGSP/ & Oryza sativa \\
\hline RIS & http://rice.plantbiology.msu.edu/ & Oryza sativa \\
\hline 1001Genomes & https://1001genomes.org/ & Arabidopsis thaliana \\
\hline SoyBase & https://soybase.org/ & Glycine max \\
\hline MaizeGDB & https://www.maizegdb.org/ & Zea mays \\
\hline JGI & https://mycocosm.jgi.doe.gov/Sorbi1/Sorbi1.home.html & Sorghum bicolor \\
\hline IWGSC & http://www.wheatgenome.org/ & Triticum aestivum \\
\hline IBSC & https://cnrgv.toulouse.inrae.fr & Hordeum vulgare \\
\hline Miyakogusa & https://www.kazusa.or.jp/lotus/ & Lotus japonicus \\
\hline GSAD & http://www.etnobiofic.cat/gsad v2/ & Asteraceae \\
\hline
\end{tabular}

\section{GENOMIKA KOMPARATIF}

Ketersediaan data genom tanaman, ekspresi gen dan perpustakaan cDNA yang berhubungan dengan respon terhadap salinitas, merupakan sumber data penting dalam penemuan gen dan jalur yang berhubungan dengan sifat toleran salinitas berdasarkan genomika komparatif. Komparasi genom plasma nutfah membuka peluang baru pemetaan genetik. Namun, genomika komparatif membutuhkan ketersedian set data ortolog, yaitu gen yang menjalankan fungsi gen serupa dan dipertahankan antar spesies yang berevolusi dari nenek moyang bersama. Saat ini, peneliti dapat mentransfer 
anotasi-anotasi gen dari tanaman model ke gen tanaman baru, meskipun kajian fungsionalnya belum sempurna. Respon cekaman salinitas antar kelompok tanaman berbeda yang dianalisis dengan genomika komparatif, akan sangat membantu peneliti untuk memprediksi dan memahami fungsi gen-gen tanaman yang baru, sehingga akan memberikan peluang untuk mengidentifikasi gen-gen toleran terhadap cekaman salinitas spesifik dan mekanisme pengaturannya.

Analisis genom lengkap 3 varietas padi, yaitu Pokkali (toleran salinitas), Nagina 22 (toleran kekeringan) dan IR 64 (sensitif) bertujuan untuk membandingkan respon cekaman salinitas dan kekeringan. Lebih dari 1,7 juta SNP dan 154.275 InDel terdeteksi antara genom referensi (Nipponbare) dan ketiga varietas, dan 401.683 SNP antara IR64 dan Pokkali dan 662.509 SNP antara IR64 dan N22, dan total 548 SNP pada 232 gen terletak di domain fungsional konservasi (Jain dkk., 2014). Selain itu, varietas padi Godawee (toleran salinitas) menghasilkan lebih dari 2,2 juta SNP dan 480.000 InDel, serta 192.249 SNP tidak bersinonim pada 31.287 gen. Gen OsHKT 2;1 menunjukkan jumlah maksimum SNP tidak bersinonim, sementara gen toleran salinitas seperti OsAPx8, OsMSR2, OsTIR1, OsHKT2;3, OsHKT1;4, dan OsSOS1 menunjukkan kelimpahan elemen pengatur cis-acting yang mengikat faktor transkripsi WRKY, superfamili faktor transkripsi yang meregulasi gen responsif sinyal pertumbuhan dan perkembangan, seperti cekaman salinitas (Singhabahu dkk., 2017).

Genomika komparatif juga telah dilaporkan pada 30 varietas tanaman padi berdaya hasil tinggi dan berdaya hasil rendah yang menghasilkan 130.317 SNP dan 15.396 InDel. Total terdapat 2.089 gen yang termasuk proses apoptosis dan aktivitas kinase, dan 262 gen di antaranya terekspresi pada jaringan reproduktif dan dianotasi sebagai reseptor terhubung protein kinase, dengan respon fotosintesis berbeda pada kondisi cekaman salinitas selama fase reproduktif, dan akhirnya berpengaruh terhadap komponen hasil dan pemulihan kembali (Lekklar dkk., 2019b). Perubahan transkrip sebagai respon terhadap salinitas juga telah dianalisis menggunakan pendekatan komparatif. Pendekatan tersebut dilakukan dengan memberikan skor persamaan dan perbedaan pola ekspresi gen yang berbeda dari populasi dengan sifat toleran salinitas yang berbeda sehingga dapat menunjukkan kontributor genetik kunci (Sahi dkk., 2006). Oleh sebab itu, untuk mengeksplorasi gen-gen toleran salinitas dibutuhkan juga data ekspresi gen, elemen-elemen pengatur dan faktor transkripsi (Tabel 2). 
Tabel 2. Pangkalan data ekspresi gen, elemen pengatur, dan faktor transkripsi

\begin{tabular}{|c|c|c|c|}
\hline Kelompok & Nama & Alamat web & $\begin{array}{l}\text { Spesies } \\
\text { Tanaman }\end{array}$ \\
\hline \multirow{6}{*}{$\begin{array}{c}\text { Ekspresi } \\
\text { gen }\end{array}$} & BAR & http://bar.utoronto.ca/ & multi \\
\hline & GENEVESTIGATOR & https://genevestigator.com/gv/ & $\begin{array}{l}\text { spesies } \\
\text { multi } \\
\text { spesies }\end{array}$ \\
\hline & AREX LITE & http://www.arexdb.org/ & $\begin{array}{l}\text { Arabidopsis } \\
\text { thaliana }\end{array}$ \\
\hline & WeigelWorld & https://www.weigelworld.org/ & $\begin{array}{l}\text { Arabidopsis } \\
\text { thaliana }\end{array}$ \\
\hline & AFGN & http://www.dbg-afgn.de/ & $\begin{array}{c}\text { Arabidopsis } \\
\text { thaliana }\end{array}$ \\
\hline & MtGEA & https://mtgea.noble.org/v3/ & $\begin{array}{l}\text { Medicago } \\
\text { truncatula }\end{array}$ \\
\hline \multirow[t]{5}{*}{$\begin{array}{l}\text { Elemen } \\
\text { pengatur }\end{array}$} & ppdb & $\begin{array}{l}\text { http://ppdb.agr.gifu-u.ac.jp/ppdb/cgi- } \\
\text { bin/index.cgi }\end{array}$ & $\begin{array}{l}\text { Multi } \\
\text { spesies }\end{array}$ \\
\hline & PlantCARE & $\begin{array}{l}\text { http://bioinformatics.psb.ugent.be/webtool } \\
\text { s/plantcare/html/ }\end{array}$ & $\begin{array}{l}\text { Multi } \\
\text { spesies }\end{array}$ \\
\hline & New PLACE & $\begin{array}{l}\text { https://www.dna.affrc.go.jp/PLACE/?actio } \\
\text { n=newplace }\end{array}$ & $\begin{array}{l}\text { Multi } \\
\text { spesies }\end{array}$ \\
\hline & AGRIS & https://agris-knowledgebase.org/ & $\begin{array}{l}\text { Arabidopsis } \\
\text { thaliana }\end{array}$ \\
\hline & AthaMap & http://www.athamap.de/ & $\begin{array}{l}\text { Arabidopsis } \\
\text { thaliana }\end{array}$ \\
\hline \multirow[t]{5}{*}{$\begin{array}{l}\text { Faktor } \\
\text { Transkripsi }\end{array}$} & PlantTFDB & http://planttfdb.cbi.pku.edu.cn/ & $\begin{array}{c}\text { multi } \\
\text { spesies }\end{array}$ \\
\hline & PInTFDB & http://plntfdb.bio.uni-potsdam.de/v3.0/ & $\begin{array}{l}\text { multi } \\
\text { spesies }\end{array}$ \\
\hline & Grassius & https://grassius.org/grasstfdb.php & $\begin{array}{l}\text { multi } \\
\text { spesies }\end{array}$ \\
\hline & RARGE & http://rarge-v2.psc.riken.jp/ & $\begin{array}{l}\text { Arabidopsis } \\
\text { thaliana }\end{array}$ \\
\hline & ATRM & http://atrm.cbi.pku.edu.cn/ & $\begin{array}{l}\text { Arabidopsis } \\
\text { thaliana }\end{array}$ \\
\hline
\end{tabular}

Faktor transkripsi responsif cekaman salinitas, misalnya $\mathrm{C}_{2} \mathrm{H}_{2}$ type zinc finger, MYB, bZIP, dan NAC, dapat diprediksi pada tanaman padi menggunakan analisis komparatif faktor transkripsi responsif cekaman salinitas yang diketahui pada Arabidopsis (Zhu dkk., 2019). Perbandingan profil transkriptom antar varietas tanaman padi juga telah dilaporkan, antara lain varietas Pokkali (toleran salinitas) dan IR29 (sensitif salinitas) (Li dkk., 2018), varietas Xian156 (toleran salinitas) dan IR28 (sensitif salinitas) (Wang dkk., 2018), dan varietas FL478 (toleran salinitas) dan IR29 (sensitif salinitas) (Mansuri dkk., 2019). Profil transkriptom antar galur dengan tetua yang sama, misalnya galur substitusi segmen kromosom asal KDML105 dan varietas KDML105 juga dilakukan untuk mempelajari sifat toleransi salinitas (Khrueasan dkk., 2019). Informasi 
genomika komparatif dan analisis transkriptom ini dapat digunakan dalam seleksi genomik. Seleksi genomik memungkinan untuk memilih kandidat berdasarkan perkiraan nilai pemuliaan genomik yang memperhitungkan pengaruh gen majemuk yang mengendalikan sifat target. Sementara kajian asosiasi lintas genom memungkinkan deteksi lokus sifat kuantitatif tanpa menggunakan populasi tetua bersegregasi.

\section{KAJIAN ASOSIASI LINTAS GENOM}

Pendekatan dasar kajian asosisasi lintas genom adalah evaluasi asosiasi antara genotip penanda SNP dan fenotip tertentu, yang diambil dari populasi galur inbrida rekombinasi, atau individu dalam jumlah besar populasi alami. Desain kajian asosiasi lintas genom secara umum adalah perbandingan antara kasus dan kontrol, atau desain kuantitatif yang membandingkan antara DNA dari tanaman yang berbeda dengan variasi fenotip untuk sifat tertentu. Kajian ini bergantung pada implemetasi desainnya untuk mendapatkan data SNP. SNP yang mempengaruhi fenotip dapat dikaji melalui 2 cara, yaitu ketika SNP menunjukkan genotip yang mempengaruhi fenotip yang disebut asosiasi langsung, sebaliknya disebut asosiasi tidak langsung, dan keduanya harus secara statistik berasosiasi. Replikasi menghasilkan generalisasi asosiasi antara SNP dan genotip dan pengaruh genetik yang relevan dengan banyak populasi. Replikasinya harus dilakukan dengan kumpulan data yang independen dari sampel yang serupa, untuk mempercayai hasil dari analisis populasi. Bila hasilnya konsisten pada studi kasus dan studi replikasi, maka asosiasi SNP dengan fenotip dapat dipercaya (Gambar 1).

Banyak studi kasus kajian asosiasi lintas genom yang telah dilaporkan sejak publikasi pertama tahun 2005. Perkembangan terkini menunjukkan bahwa kajian ini menjadi metode yang paling berhasil untuk mengidentifikasi penyebab genetik dari sifat kuantitatif yang kompleks. Metode tersebut juga telah digunakan untuk menginvestigasi asosiasi antara variasi genetik dan sifat pertanian penting, termasuk sifat toleran salinitas. Yu dkk. (2018) melaporkan kajian asosiasi lintas genom terhadap 295 aksesi padi saat fase perkecambahan, menghasilkan 12 puncak asosiasi yang terdistribusi pada 7 kromosom, dan mengidentifikasi 79 gen kandidat dengan 17 gen berkontribusi terhadap sifat toleran salinitas saat fase perkecambahan. Lekklar dkk. (2019a) menggunakan metode tersebut untuk mengevaluasi 104 aksesi padi saat fase berbunga, diketahui terdapat 200 lokus yang mengandung 448 SNP pada ekson, dan menghasilkan 146 gen dengan 4 wilayah yang mengandung SNP signifikan berada pada kromosom 1, 2, 8 dan 12, sementara banyak di antaranya yang baru, dengan anotasi yang konsisten dengan keterlibatan sifat toleran salinitas tanaman dan sifat agronomi. 


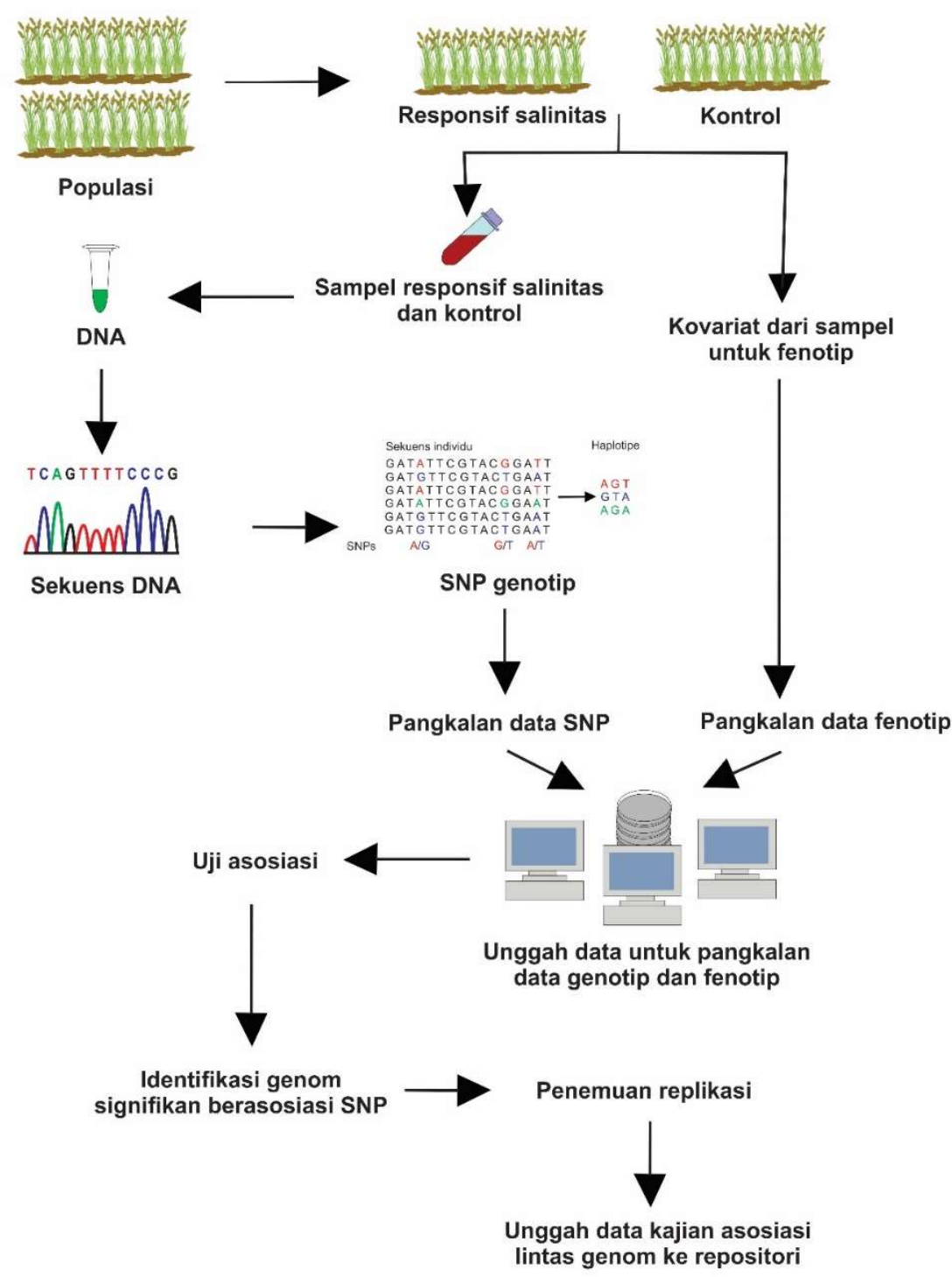

Gambar 1. Model kajian asosiasi lintas genom yang diimplementasikan untuk mempelajari cekaman salinitas pada tanaman padi

Liu dkk. (2019) berhasil mengidentifikasi gen-gen yang berkaitan dengan sifat toleran salinitas dan sifat agronomi melalui kajian asosiasi lintas genom terhadap 708 aksesi padi yang ditanam di sawah lahan salin, menghasilkan 2.255 penanda sinyal asosiasi sifat yang terdistribusi pada 903 gen, dan mengidentifikasi 15 kandidat gen, termasuk 5 gen yang diketahui dan 10 gen baru, serta 7 aksesi yang menunjukkan asosiasi signifikan dengan hasil biji yang baik pada kondisi cekaman salinitas. Yuan dkk. (2020) tidak hanya mengidentifikasi gen-gen kandidat sifat toleran salinitas berdasarkan lokus sifat kuantiatif yang diidentifikasi oleh kajian asosisasi lintas genom, namun juga berhasil mengungkap dasar genetiknya, dimana OsSTL1 homolog dengan SRP1 pada 
Arabidopsis, dan hap1 dari OsSTL1 diidentifikasi sebagai haplotipe superior dan nonsinonim SNP yang kemungkinan besar adalah situs fungsional, dan memunculkan dasar baru bagi pemuliaan molekuler dan analisis fungsional sifat toleran salinitas bahwa level sifat toleran salinitas dapat ditingkatkan dengan mengkombinasikan haplotipe dari gengen yang berbeda.

Aplikasi kajian asosiasi lintas genom untuk gen toleran salinitas pada tanaman padi masih sangat awal, namun terdapat potensi besar untuk mengidentifikasi keragaman alami lokus yang berasosiasi dengan sifat agronomi penting, serta variasi alel kandidat gen yang mendasari sifat kuantitatif dan kompleks. Gen-gen kandidat yang berhasil diidentifikasi dapat digunakan dalam penentuan prioritas untuk kajian yang lebih intensif, yaitu gen-gen mana yang dipilih untuk kajian biokimia dan fisiologis. Meskipun keterbatasan metodologi dan masalah resolusi menyebabkan varian dan gen yang berasosiasi dengan sifat tertentu masih sulit diidentifikasi, namun saat ini memungkinkan dilakukan melalui pendekatan komputasi untuk menyelesaikan masalah tersebut. Integrasi pangkalan data berbasis web, seperti informasi geografis, polimorfisme, dan kajian asosiasi lintas genom, sangat memudahkan pendekatan genetika maju dan mundur untuk mempelajari toleransi tanaman padi terhadap cekaman salinitas.

\section{POTENSI PEMANFAATAN GEN TOLERAN SALINITAS UNTUK PEMULIAAN PADI}

Gen-gen toleran salinitas yang berhasil ditemukan dapat dimanfaatkan untuk silang balik berbantuan penanda, seleksi berbantuan penanda, dan seleksi genomik. Secara teknis juga dapat dilakukan melalui seleksi in vitro, rekayasa genetika, dan pengeditan genom. Sebagai contoh, Linh dkk. (2012) menerapkan silang balik berbantuan penanda untuk meningkatkan level sifat toleran salinitas tanaman padi varietas BT7, menggunakan introgresi lokus sifat kuantitatif Saltol asal donor varietas FL478. Semua galur yang dihasilkan memiliki alel Saltol yang sama dengan tetua donor FL478, namun memiliki penampilan agronomi yang sama dengan tetua induk BT7. Metode berbeda dilakukan Rana dkk. (2019) melalui introgresi gen hst1 untuk mentransfer sifat toleran salinitas dari tanaman padi varietas Kaijin ke varietas Yukinkomai yang memiliki sifat daya hasil tinggi menggunakan seleksi berbantuan penanda SNP. Populasi YNU31-2-4 yang dihasilkan dalam 6 generasi selama 17 bulan, merupakan kandidat varietas yang toleran salinitas pada fase bibit dan reproduktif.

Shi dkk. (2017) dan Lekklar dkk. (2019a) menyarankan hasil kajian asosiasi lintas genom digunakan dalam seleksi genomik, yaitu metode yang mengasumsikan bahwa efek aditif banyak gen mengontrol varian genetik suatu sifat, pada skala ratusan hingga 
ribuan varian masing-masing dengan efek yang kecil, namun hingga saat ini belum ada laporan seleksi genomik untuk sifat toleran salinitas pada tanaman padi. Selain itu, rekayasa genetika juga sangat potensial untuk dilakukan karena saat ini sudah banyak dihasilkan tanaman transgenik toleran salinitas melalui pendekatan overekspresi. Misalnya untuk protein MYB yang saat ini telah banyak diidentifikasi pada berbagai spesies tanaman melalui kajian asosiasi lintas genom. Tang dkk. (2019) melakukan overekspresi gen famili MYB, yaitu OsMYB6, sehingga meningkatkan sifat toleran salinitas pada tanaman padi transgenik, dan terdapat indikasi bahwa peningkatan level sifat toleran salinitas tersebut tanpa memberikan pengaruh negatif selama pertumbuhan dan perkembangan tanaman padi.

Pengeditan genom melalui sistem CRISPR/Cas9 telah banyak digunakan, namun aplikasinya untuk memperbaiki varietas elit padi masih sangat sedikit dilaporkan. Zhang dkk. (2019) menggunakannya untuk meningkatkan level sifat toleran salinitas dengan merekayasa vektor ekspresi Cas9-OsRR22-gRNA dengan target gen OsRR22 pada tanaman padi. Pendekatan berbeda dilakukan di laboratorium Carvalho (2019) yang melakukan validasi terhadap kandidat-kandidat gen toleran salinitas hasil kajian asosisasi lintas genom, menggunakan mekanisme knock out sistem CRISPR/Cas9 untuk masing-masing gen secara individual, dan melihat responnya terhadap perlakuan salinitas yang berbeda. Selain itu, mekanisme knock in juga telah dilakukan di laboratorium tersebut meskipun hingga saat ini belum ada publikasi ilmiah yang dapat diakses publik. Kombinasi metode pemuliaan molekuler memang sangat diperlukan untuk memanfaatkan gen-gen toleran salinitas yang berasosiasi dengan sifat-sifat tanaman padi yang bernilai ekonomi tinggi, sehingga efektif, efisien, dan ekonomis. Pemanfaatannya untuk pemuliaan tanaman padi toleran salinitas tentu mendukung kebijakan swasembada pangan nasional, serta pertanian berkelanjutan di era genomika.

\section{KESIMPULAN}

Genomika telah memberikan kontribusi dalam penemuan gen-gen toleran salinitas tanaman padi, khususnya melalui genomika komparatif dan kajian asosiasi lintas genom. Gen-gen toleran salinitas yang ditemukan dapat digunakan melalui silang balik berbantuan penanda, seleksi berbantuan penanda, dan seleksi genomik, namun saat ini belum secara optimal dimanfaatkan. Pendekatan bioteknologi, seperti rekayasa genetika dan pengeditan genom juga belum banyak memanfaatkan gen-gen toleran salinitas yang telah ditemukan. Meskipun demikian, tren penelitian yang memanfaatkan pangkalan data berbasis web diperkirakan terus meningkat karena murah, relatif mudah, 
dan mampu menghasilkan data prediktif. Pangkalan data yang akan terus berkembang, tentu harus dapat dimanfaatkan oleh peneliti dan pemulia tanaman di Indonesia. Pemanfaatannya diharapkan dapat mengakselerasi pemuliaan tanaman padi toleran salinitas yang berkontribusi pada pembangunan pertanian berkelanjutan.

\section{DAFTAR PUSTAKA}

Abhayawickrama, B., D. Gimhani, N. Kottearachchi, V. Herath, D. Liyanage dan P. Senadheera. 2020. In silico identification of QTL-based polymorphic genes as salt-responsive potential candidates through mapping with two reference genomes in rice. Plants. 9: 233. DOI: 10.3390/plants9020233

Balai Besar Penelitian Tanaman Padi (BB Padi). 2010. Deskripsi Varietas Unggul Baru Padi 2010. Subang: Badan Penelitian dan Pengembangan Pertanian, Kementerian Pertanian.

Balai Besar Penelitian Tanaman Padi (BB Padi). 2018. Deskripsi Varietas Unggul Baru Padi 2018. Subang: Badan Penelitian dan Pengembangan Pertanian, Kementerian Pertanian.

Bindusree, G., P. Natarajan, S. Kalva dan P. Madasamy. 2017. Whole genome sequencing of Oryza sativa L. cv. Seeragasamba identifies a new fragrance allele in rice. PloS ONE. 12(11): e0188920. DOI: 10.1371/journal.pone.0188920

Carvalho, U. 2019. How CRISPR/Cas9 can help unravel salt stress responses in rice. $<$ http://www.global-engage.com/agricultural-biotechnology/how-crispr-cas9-canhelp-unravel-salt-stress-responses-in-rice/>. Diakses pada 26 Agustus 2020.

Chutimanukul, P., B. Kositsup, K. Plaimas, T. Buaboocha, M. Siangliw, T. Toojinda, L. Comai dan S. Chadchawan. 2018. Photosynthetic responses and identification of salt tolerance genes in a chromosome segment substitution line of 'Khao dawk Mali 105' rice. Environmental and Experimental Botany. 155: 497 - 508. DOI: 10.1016/j.envexpbot.2018.07.019

Cubero, M.J.A., M. Saiz, B. M. García, S. M. Sayalero, C. Entrala, J. A. Lorente, dan L. J. M. Gonzalez. 2017. Next generation sequencing: an application in forensic sciences? Annals of Human Biology. 44 (7): 581-592. DOI: 10.1080/03014460.2017.1375155

Fu, Y.B. 2017. The vulnerability of plant genetic resources conserved ex situ. Crop Science. 57 (5): 2314-2328. DOI: 10.2135/cropsci2017.01.0014

Goff, S.A., D. Ricke, T. H. Lan, G. Presting, R. Wang, M. Dunn, J. Glazebrook, A. Sessions, P. Oeller, H. Varma, D. Hadley, D. Hutchison, C. Martin, F. Katagiri, B. M. Lange, T. Moughamer, Y. Xia, P. Budworth, J. Zhong, T. Miguel, U. Paszkowski, S. Zhang, M. Colbert, W. Sun, L. Chen, B. Cooper, S. Park, T. C. Wood, L. Mao, P. Quail, R. Wing, R. Dean, Y. Yu, A. Zharkikh, R. Shen, S. Sahasrabudhe, A. Thomas, R. Cannings, A. Gutin, D. Pruss, J. Reid, S. Tavtigian, J. Mitchell, G. Eldredge, T. Scholl, R. M. Miller, S. Bhatnagar, N. Adey, T. Rubano, N. Tusneem, R. Robinson, J. Feldhaus, T. Macalma, A. Oliphant dan S. Briggs. 2002. A draft sequence of the rice genome (Oryza sativa L. ssp. japonica). Science. 296 (5565): 92 - 100. DOI: 10.1126/science.1068275 
Gupta B. dan B. Huang. 2014. Mechanism of salinity tolerance in plants: physiological, biochemical and molecular characterization. International Journal of Genomics. 2014: 701596. DOI: 10.1155/2014/701596

Hao, W. dan H.X. Lin. 2010. Toward understanding genetic mechanisms of complex traits in rice. Journal of Genetics and Genomics. 37(10): 653-666. DOI: 10.1016/S1673-8527(09)60084-9

Horie, T., I. Karahara dan M. Katsuhara. 2012. Salinity tolerance mechanisms in glycophytes: An overview with the central focus on rice plants. Rice. 5: 11. DOI: 10.1186/1939-8433-5-11

Huang, X. dan B. Han. 2014. Natural variations and genome-wide association studies in crop plants. Annual Review of Plant Biology. 65: 531 - 51. DOI: 10.1146/annurevarplant-050213-035715

Jain, M, K.C. Moharana, R. Shankar, R. Kumari dan R. Garg. 2014. Genome-wide discovery of DNA polymorphisms in rice cultivars with contrasting drought and salinity stress response and their functional relevance. Plant Biotechnology Journal. 12(2): 253-264. DOI: 10.1111/pbi.12133

Jain, R., J. Jenkins, S. Shu, M. Chern, J. A. Martin, D. Copetti, P. Q. Duong, N. T. Pham, D. A. Kudrna, J. Talag, W. S. Schackwitz, A. M. Lipzen, D. Dilworth, D. Bauer, J. Grimwood, C. R. Nelson, F. Xing, W. Xie, K. W. Barry, R. A. Wing, J. Schmutz, G. Li dan P. C. Ronald. 2019. Genome sequence of the model rice variety KitaakeX. BMC Genomis. 20: 905. DOI: 10.1186/s12864-019-6262-4

Kaewneramit, T., T. Buaboocha, P. Sangchai dan N. Wutipraditkul. 2019. Oscam1-1 overexpression in the transgenic rice mitigated salt-induced oxidative damage. Biologia Plantarum. 63: 335-342, 2019. DOI: 10.32615/bp.2019.039

Khrueasan, N., P. Chutimanukul, K. Plaimas, T. Buaboocha, M. Siangliw, T. Toojinda, L. Comai dan S. Chadchawan. 2019. Comparison between the transcriptomes of 'KDML105' rice and a salt-tolerant chromosome segment substitution line. Genes. 10 (10): 742. DOI: 10.3390/genes10100742

Kusmiyati, F., Sutarno, M.G.A. Sas dan B. Herwibawa. 2018. Mutagenic effects of gamma rays on sobean (Glycine max L.) germination and seedlings. IOP Conference Series: Earth and Environmental Science. 102: 012059. DOI: 10.1088/1755-1315/102/1/012959

Lekklar, C., M. Pongpanich, D. Suriya-arunroj, A. Chinpongpanich, H. Tsai, L. Comai, S. Chadchawan dan T. Buaboocha. 2019a. Genome-wide association study for salinity tolerance at the flowering stage in a panel of rice accessions from Thailand. BMC Genomics. 20 (1): 76. DOI: 10.1186/s12864-018-5317-2

Lekklar, C., D. Suriya-arunroj, M. Pongpanich, L. Comai, B. Kositsup, S. Chadchawan dan T. Buaboocha. 2019b. Comparative genomic analysis of rice with contrasting photosynthesis and grain production under salt stress. Genes. 10: 562. DOI: 10.3390/genes 10080562

Li, Y.F., Y. Zheng, L. R. Vemireddy, S. K. Panda, S. Jose, A. Ranjan, P. Panda, G. Govindan, J. Cui, K. Wei, M. W. Yaish, G. C. Naidoo dan R. Sunkar. 2018. Comparative transcriptome and translatome analysis in contrasting rice 
genotypes reveals differential mRNA translation in salt-tolerant Pokkali under salt stress. BMC Genomics. 19: 935. DOI: 10.1186/s12864-018-5279-4

Linh, L. H., T. H. Linh, T. D. Xuan, L. H. Ham, A. M. Ismail dan T. D. Khanh. 2012. Molecular breeding to improve salt tolerance of rice (Oryza sativa L.) in the red river delta of Vietnam. International Journal of Plant Genomics. 2012: 949038. DOI: $10.1155 / 2012 / 949038$

Liu, C., K. Chen, X. Zhao, X. Wang, C. Shen, Y. Zhu, M. Dai, X. Qiu, R. Yang, D. Xing, Y. Pang dan J. Xu. 2019. Identification of genes for salt tolerance and yieldrelated traits in rice plants grown hydroponically and under saline field conditions by genome-wide association study. Rice. 12: 88. DOI: 10.1186/s12284-0190349-z

Liu, L., Y. Li, S. Li, N. Hu, Y. He, R. Pong, D. Lin, L. Lu dan M. Law. 2012. Comparison of next-generation sequencing systems. Journal of Biomedicine and Biotechnology. 2012: 251364. DOI: 10.1155/2012/251364

Mansuri, R. M., Z. S. Shobbar, N. B. Jelodar, M. R. Ghaffari, G. A. Nematzadeh dan S. Asari. 2019. Dissecting molecular mechanisms underlying salt tolerance in rice: a comparative transcriptional profiling of the contrasting genotypes. Rice. 12: 13. DOI: $10.1186 / \mathrm{s} 12284-019-0273-2$

Pereira, R., J. Oliveira dan M. Sousa. 2020. Bioinformatics and computational tools for next generation sequencing analysis in clinical genetics. Journal of Clinical Medicine. 9: (1): 132. DOI: 10.3390/jcm9010132

Rad, H.E., F. Aref dan M. Rezaei. 2012. Response of rice to different salinity levels during different growth stage. Research Journal of Applied Sciences, Engineering and Technology. 4(17): 3040 - 3047.

Rana, M.M., T. Takamatsu, M. Baslam, K. Kaneko, K. Itoh, N. Harada, T. Sugiyama, T. Ohnishi, T. Kinoshita, H. Takagi dan T. Mitsui. 2019. Salt tolerance improvement in rice through efficient SNP marker-assisted selection coupled with speedbreeding. International Journal of Molecular Sciences. 20: 2585. DOI: 10.3390/ijms20102585

Razzaque, S., S. M. Elias, T. Haque, S. Biswas, G. M. N. A. Jewel, S. Rahman, X. Weng, A. M. Ismail, H. Walia, T. E. Juenger dan Z. I. Seraj. 2019. Gene expression analysis associated with salt stress in a reciprocally crossed rice population. Scientific Reports. 9: 8249. DOI: 10.1038/s41598-019-44757-4

Sahi, C., A. Singh, K. Kumar, E. Blumwald dan A. Grover. 2006. Salt stress response in rice: genetics, molecular biology, and comparative genomics. Functional and Integrative Genomics. 6: 263-284. DOI: 10.1007/s10142-006-0032-5

Sankar, P.D., M.A.A.M. Saleh dan C.I. Selvaraj. 2011. Rice breeding for salt tolerance. Research in Biotechnology. 2: 1-10.

Senadhira, D., F.J. Zapata-Arias, G.B. Gregorio, M.S. Alejar, H.C. de la Cruz, T.F. Padolina dan A.M. Galvez. 2002. Development of first salt-tolerant rice cultivar through indica/indica anther culture. Field Crops Research. 76(2-3): 103-110. DOI: 10.1016/S0378-4290(02)00032-1 
Shi, Y., L. Gao, Z. Wu, X. Zhang, M. Wang, C. Zhang, F. Zhang, Y. Zhou dan Z. Li. 2017. Genome-wide association study of salt tolerance at the seed germination stage in rice. BMC Plant Biology. 17: 92. DOI: 10.1186/s12870-017-1044-0

Singhabahu, S., C. Wijesinghe, D. Gunawardana, M.D. Senarath-Yapa, M. Kannangara, R. Edirisinghe dan H.W.V. Dissanayake. 2017. Whole genome sequencing and analysis of Godawee, a salt tolerant indica rice variety. Rice Research: Open Access. 5: 177. DOI: 10.4172/2375-4338.1000177

Tang, Y. X. Bao, Y. Zhi, Q. Wu, Y. Guo, X. Yin, L. Zeng, J. Li, J. Zhang, W. He, W. Liu, Q. Wang, C. Jia, Z. Li dan K. Liu. 2019. Overexpression of a MYB family gene, OsMYB6, increases drought and salinity stress tolerance in transgenic rice. Frontiers in Plant Science. 10: 168. DOI: 10.3389/fpls.2019.00168

Wang, J., J. Zhu, Y. Zhang, F. Fan, W. Li, F. Wang, W. Zhong, C. Wang dan J. Yang. 2018. Comparative transcriptome analysis reveals molecular response to salinity stress of salt-tolerant and sensitive genotypes of indica rice at seedling stage. Scientific Reports. 8: 2085. DOI: 10.1038/s41598-018-19984-w

Yu, J., W. Zhao, W. Tong, Q. He, M. Y. Yoon, F. P. Li, B. Choi, E. B. Heo, K. W. Kim dan Y. J. Park. 2018. A genome-wide association study reveals candidate genes related to salt tolerance in rice (Oryza sativa) at the germination stage. International Journal of Molecular Science. 19 (10): 3145. DOI: 10.3390/ijms19103145

Yu, J., S. Hu, J. Wang, G. K. S. Wong, S. Li, B. Liu, Y. Deng, L. Dai, Y. Zhou, X. Zhang, M. Cao, J. Liu, J. Sun, J. Tang, Y. Chen, X. Huang, W. Lin, C. Ye, W. Tong, L. Cong, J. Geng, Y. Han, L. Li, W. Li, G. Hu, X. Huang, W. Li, J. Li, Z. Liu, L. Li, J. Liu, Q. Qi, J. Liu, L. Li, T. Li, X. Wang, H. Lu, T. Wu, M. Zhu, P. Ni, H. Han, W. Dong, X. Ren, X. Feng, P. Goff, X. Li, H. Wang, X. Xu, W. Zhai, Z. Xu, J. Zhang, S. He, J. Zhang, J. Xu, K. Zhang, X. Zheng, J. Dong, W. Zeng, L. Tao, J. Ye, J. Tan, X. Ren, X. Chen, J. He, D. Liu, W. Tian, C. Tian, H. Xia, Q. Bao, G. Li, H. Gao, T. Cao, J. Wang, W. Zhao, P. Li, W. Chen, X. Wang, Y. Zhang, J. Hu, J. Wang, S. Liu, J. Yang, G. Zhang, Y. Xiong, Z. Li, L. Mao, C. Zhou, Z. Zhu, R. Chen, B. Hao, W. Zheng, S. Chen, W. Guo, G. Li, S. Liu, M. Tao, J. Wang, L. Zhu, L. Yuan dan H. Yang. 2002. A draft sequence of rice genome (Oryza sativa L. ssp. indica). Science. 296 (5565): 79 - 92. DOI: 10.1126/science.1068037

Yuan, J., X. Wang, Y. Zhao, N.U. Khan, Z. Zhao, Y. Zhang, X. Wen, F. Tang, F. Wang dan Z. Li. 2020. Genetic basis and identification of candidate genes for salt tolerance in rice by GWAS. Scientific Reports. 10: 9958. DOI: 10.1038/s41498020-66604-7

Zhang, A., Y. Liu, F. Wang, T. Li, Z. Chen, D. Kong, J. Bi, F. Zhang, X. Luo, J. Wang, J. Tang, X. Yu, G. Liu dan L. Luo. 2019. Enhanced rice salinity tolerance via CRISPR/Cas9-targeted mutagenesis of the OsRR22 gene. Molecular Breeding. 39: 47. DOI: 10.1007/s11032-019-0954-y

Zhu, M., H. Xie, X. Wei, K. Dossa, Y. Yu, S. Hui, G. Tang, X. Zeng, Y. Yu, P. Hu dan J. Wang. 2019. WGCNA analysis of salt-responsive core transcriptome identifies novel hub genes in rice. Genes. 10(9): 719. DOI: 10.3390/genes10090719 